\title{
Oral Mucositis related to Radiotherapy for Head and Neck cancer: Evaluation of the Effectiveness of a New Anti-inflammatory Product Containing Verbascoside, Polyvinylpyrrolidone, Hyaluronic Acid $\left(\right.$ Mucosyte ${ }^{\circledR}$ ) \\ Rossella Di Franco', Matteo Muto ${ }^{3}$, Vincenzo Ravo², Domenico Borrelli ${ }^{3}$, Alfonsina Pepe ${ }^{3}$, Sara Falivene ${ }^{1 *}$, Angela Argenone $^{2}$, Giovanna
} Guida ${ }^{2}$ and Paolo Muto ${ }^{2}$

${ }^{1}$ Radiation Oncology, Second University of Naples, Naples, Italy

${ }^{2}$ Radiation Oncology, Istituto Nazionale per lo Studio e la Cura dei Tumori-Fondazione "Giovanni Pascale" IRCCS, Naples, Italy

${ }^{3}$ Radiation Oncology Emicenter, Casavatore, Naples, Italy

\begin{abstract}
Introduction: Mucositis is a greater complication of chemotherapy and radiotherapy in head and neck cancer, linked with risk of interruption of therapy. Toxicity is related to reactive oxygen species, which cause transcription ofNF-kB, iNOS, AP-1, pro-inflammatory cytokines.

Objectives: We have conducted a retrospective study to evaluate the preventive effect of Verbascoside (Mucosyte ${ }^{\circledR}$ ) in the onset of mucositis due to radiotherapy.

Methods: We evaluated 172 patients treated with radiotherapy, divided in two arms: Control Group of 83 patients treated with 3DCRT or IMRT and with Verbascoside (Mucosyte ${ }^{\circledR}$ ) prescribed at appearance of mucositis, and on the other hand Mucosyte Group of 89 patients treated with 3DCRT, IMRT, Tomotherapy who received Mucosyte ${ }^{\circledR}$ previously and until two weeks from the end of radiotherapy. Radiotherapy doses were between 30-71.3Gy delivered with multiple coplanar fields. We calculated the percentage of patients with mucositis grade 1,2, 3 or 4 in the two groups of patients, absolute risk reduction (ARR), relative risk (RR), relative risk reduction (RRR) and odds ratio (OR). We evaluated acute toxicity and Mean Dose (Dmean) to parotid glands to determine techniques' influence to onset of mucositis.
\end{abstract}

Results:The percentage of high toxicity is lower in Mucosyte Group. We calculated: risk of adverse events in MG $\mathrm{PM}=0.17$; Odds $=0.20$; risk of adverse events in $\mathrm{CG} P \mathrm{P}=0.52$; Odds $=1.08$; Odds Ratio $\mathrm{OR}=0.19$; relative risk $\mathrm{RR}$ : 0.33 ; relative risk reduction RRR: 0.67 ; absolute risk reduction ARR: 0.35 . All parameters showed the effectiveness of Verbascoside in management of patients with head and neck cancer.

Conclusions: Using Mucosyte ${ }^{\circledR}$ previously and until two weeks from the end of radiotherapy the incidence of muscositis is lower but this result is influenced also by technique. Xerostomia, mycosis and pain are much lower in the patient that used Mucosyte ${ }^{\circledR}$ in prevention independently from technique used.

Keywords: Mucositis; Radiotherapy; Head and neck cancer; Verbascoside

Abbreviations: Control Group (CG); Mucosyte Group (MG); Absolute risk reduction (ARR); Relative Risk (RR); Relative Risk Reduction (RRR); Odds Ratio (OR); Three dimensional conformal radiotherapy (3DCRT); Image Modulate Radiotherapy (IMRT)

\section{Introduction}

Management of head and neck cancer includes surgery, chemotherapy, radiotherapy and biological therapy according with histological type, tumour side and staging. These approaches have side effects that can compromise the quality of life of patients. Randomized trials and meta-analyses [1-5] had demonstrated that in the treatment of head and neck cancer the use of concurrent chemo radiotherapy ensures a better organ preservation, locoregional control, and longer survival but results a greater toxicity. Oral complications from chemotherapy and/or radiation therapy are mucositis, xerostomia, bacterial, fungal, or viral infection, dental caries, dysgeusia, osteoradionecrosis [6-11]. Mucositis represents the most frequent complication of chemotherapy and radiotherapy, associated to dehydration, malnutrition and risk of interruption of the anticancer therapy [12]. Chemotherapy induces mucositis usually from 7 to 14 days from the beginning. Radiotherapy induces mucositis, alterating salivary gland function and risk of mucosal infection at doses of 15-20 Gy with standard fractionation, and can induce ulcerative mucositis at doses of $30 \mathrm{~Gy}$. Chemotherapyinduced mucositis is generally limited to non-keratinized mucosae, while radiation-induced mucositis affects those tissues in the radiation field [13]. The pain due to mucositis can have a high intensity requiring the use of parenteral opioid analgesics, and causing the interruption of the planned cancer therapy [14-20]. It would be desirable to prevent the development of mucositis, maintaining locoregional tumor control. Few agents have been proven effective in prevention of mucositis in head and

${ }^{*}$ Corresponding author: Sara Falivene, Radiation Oncology, Second University of Naples, Pza Miraglia, 80131 Napoli, Italy, Tel: 081 5903277; Fax: 081 5903809; E-mail:sara.falivene@gmail.com

Received June 05, 2014; Accepted September 27, 2014; Published September 30,2014

Citation: Di Franco R, Muto M, Ravo V, Borrelli D, Pepe A, et al. (2014) Oral Mucositis related to Radiotherapy for Head and Neck cancer: Evaluation of the Effectiveness of a New Anti-inflammatory Product Containing Verbascoside, Polyvinylpyrrolidone, Hyaluronic Acid (Mucosyte ${ }^{\circledR}$ ). Pharm Anal Acta 5: 312 doi:10.4172/2153-2435.1000312

Copyright: (c) 2014 Di Franco R, et al. This is an open-access article distributed under the terms of the Creative Commons Attribution License, which permits unrestricted use, distribution, and reproduction in any medium, provided the original author and source are credited. 
Citation: Di Franco R, Muto M, Ravo V, Borrelli D, Pepe A, et al. (2014) Oral Mucositis related to Radiotherapy for Head and Neck cancer: Evaluation of the Effectiveness of a New Anti-inflammatory Product Containing Verbascoside, Polyvinylpyrrolidone, Hyaluronic Acid (Mucosyte ${ }^{\circledR}$ ). Pharm Anal Acta 5: 312. doi:10.4172/2153-2435.1000312

neck cancer [21]. Usually these do not interfere with the effectiveness of cancer treatment. The formulation of the Mucosyte ${ }^{\oplus}$ is centered on the presence of Verbascoside, obtained with biotechnological procedures by culture of stem cells of Verbena officinalis and has high antiinflammatory activity. Moreover hyaluronic acid (sodium salt), helps the reparative processes and re-epithelialization, and polyvinylpyrrolidone (PVP), which for its muco-adhesive characteristics, provide a protective film of the oral mucosa [22].

Aim This is a multicenter retrospective observational study evaluating the effectiveness of an anti-inflammatory product containing Verbascoside, Polyvinylpyrrolidone, Hyaluronic Acid (Mucosyte ${ }^{\circledast}$ ) in the prevention of radiotherapy-induced mucositis in the treatment of head and neck cancer.

\section{Materials and Methods}

We evaluated 172 patients treated with radiation therapy for head

\begin{tabular}{|c|c|c|}
\hline Patients (No) & $\begin{array}{c}\text { GC } \\
83\end{array}$ & $\begin{array}{c}\text { MG } \\
89\end{array}$ \\
\hline $\begin{array}{l}\text { Age } \\
\text { Mean } \\
\text { SD (s) } \\
\text { Median } \\
\text { Range }\end{array}$ & $\begin{array}{c}61.1 \\
11.8 \\
62 \\
(30-86)\end{array}$ & $\begin{array}{c}69.3 \\
15.4 \\
71 \\
(24-97)\end{array}$ \\
\hline $\begin{array}{c}\text { Primary Tumor site } \\
\text { Nasopharynx } \\
\text { Oral cavity } \\
\text { Salivary glands } \\
\text { Oropharynx } \\
\text { Nasal cavity and paranasal sinuses } \\
\text { Hypopharynx } \\
\text { Larynx } \\
\text { Thyroid } \\
\text { Ear } \\
\text { Cervical esophagus } \\
\text { Unknown primary tumour (UPT) }\end{array}$ & $\begin{array}{c}9(11 \%) \\
26(31 \%) \\
2(2 \%) \\
9(11 \%) \\
4(5 \%) \\
1(1 \%) \\
19(23 \%) \\
5(6 \%) \\
5(6 \%) \\
0(0 \%) \\
3(4 \%)\end{array}$ & $\begin{array}{c}12(13 \%) \\
21(24 \%) \\
2(2 \%) \\
9(10 \%) \\
5(6 \%) \\
1(1 \%) \\
28(32 \%) \\
1(1 \%) \\
3(3 \%) \\
5(6 \%) \\
2(2 \%)\end{array}$ \\
\hline $\begin{array}{c}\text { Hystologic type } \\
\text { Squamous Carcinoma } \\
\text { Epidermoid Carcinoma } \\
\text { Adenocarcinoma } \\
\text { Mucoepidermoid Carcinoma } \\
\text { Spinocellular Carcinoma } \\
\text { Hodgkin lymphoma } \\
\text { NHL } \\
\text { Melanoma } \\
\text { Ca papillary } \\
\text { Ca follicular } \\
\text { Undifferentiated carcinoma }\end{array}$ & $\begin{array}{c}43(52 \%) \\
29(35 \%) \\
3(4 \%) \\
2(2 \%) \\
1(1 \%) \\
0 \\
0 \\
0 \\
3(4 \%) \\
2(2 \%) \\
0\end{array}$ & $\begin{array}{c}37(42 \%) \\
22(25 \%) \\
5(5 \%) \\
0 \\
3(3 \%) \\
2(2 \%) \\
3(3 \%) \\
2(2 \%) \\
2(2 \%) \\
0 \\
13(15 \%)\end{array}$ \\
\hline $\begin{array}{c}\text { Chemotherapy } \\
\text { No } \\
\text { pre-RT } \\
\text { concomitant } \\
\text { pre-RT+concomitant }\end{array}$ & $\begin{array}{c}27(33 \%) \\
28(34 \%) \\
19(23 \%) \\
9(11 \%)\end{array}$ & $\begin{array}{c}62(70 \%) \\
14(16 \%) \\
2(2 \%) \\
11(12 \%)\end{array}$ \\
\hline $\begin{array}{c}\text { Radiotherapy } \\
T \text { (only) } \\
T+N \\
N \text { (only) }\end{array}$ & $\begin{array}{c}9(11 \%) \\
64(77 \%) \\
10(12 \%)\end{array}$ & $\begin{array}{c}35(39 \%) \\
47(53 \%) \\
8(9 \%)\end{array}$ \\
\hline
\end{tabular}

Table 1: Characteristics of patients.

\begin{tabular}{|c|c|}
\hline \multicolumn{2}{|c|}{ EORTC/RTOG - Scoring system for mucositis related to radiotherapy } \\
\hline Grade 0 & No reaction \\
\hline Grade $\mathbf{1}$ & Mild erythema \\
\hline Grade 2 & Severe erythema \\
\hline Grade 3 & Spotted mucositis \\
\hline Grade $\mathbf{4}$ & Confluent mucositis \\
\hline
\end{tabular}

Table 2: Scale for oral mucositis used. and neck cancer, divided in two groups: a Control Group (CG) of 83 patients treated at the UOC of Radiotherapy of the Istituto Nazionale per lo Studio e la Cura dei Tumori-Fondazione "Giovanni Pascale" IRCCS, of Naples, and a Mucosyte Group (MG) of 89 patients treated at the Muto-Onlus Foundation of Naples.

Before starting radiotherapy, all patients were submitted to a complete clinical dental examination and received detailed oral hygiene instructions. Patients of the first group (CG) were treated with 3DCRT or IMRT (with linear accelerator) technique; patients of the second group (MG) were treated with 3DCRT, IMRT (with linear accelerator or Tomotherapy). A new anti-inflammatory product fluid containing Verbascoside, Polyvinylpyrrolidone, Hyaluronic Acid (Mucosyte ${ }^{\circledR}$ ) was prescribed usually at the appearance of mucositis to the CG group, while the same substance was prescribed ( $15 \mathrm{ml}$ thrice daily) to the MG group in a preventive attempt from the beginning until two weeks from the end of radiotherapy.

The main characteristics of the patients are shown in Table 1.

Depending on the stage, the purpose of treatment (curative or palliative), and risk factors, patients were treated with doses between 30 and $71.3 \mathrm{~Gy}$, by fractions of 1.8-2.6Gy/die, 5 days/week, using multiple coplanar fields. For each patient it was evaluate the presence of mucositis, mycosis, dysphagia, pain, xerostomia. A clinical exam of the mucous membranes was performed weekly by using the EORTC/ RTOG (Dische) scoring system for mucositis related to radiotherapy (Table 2).

We also evaluated treatment plans for all patients considering the Dmean delivered to the parotid glands to determine whether the use of different techniques, allowing the delivery of a lower dose to the parotid glands, might influence the onset of mucositis. We calculated the percentage of patients with mucositis grade $1,2,3$ or 4 in the two groups of patients, and calculated the absolute risk reduction (ARR), relative risk (RR), the relative risk reduction (RRR) and odds ratio (OR). It was evaluated if there was a correlation between the grade of mucositis and the pre-RT chemotherapy or concomitant chemotherapy treatment. In all cases we verified whether there was a correlation with the use in the prevention of Mucosyte ${ }^{\circledR}$.

\begin{tabular}{|c|c|c|}
\hline Patients (No) & $\begin{array}{c}\text { GC } \\
83\end{array}$ & $\begin{array}{c}\text { MG } \\
89\end{array}$ \\
\hline $\begin{array}{c}\text { Mucositis } \\
\text { grade } 0 \\
\text { grade } 1 \\
\text { grade } 2 \\
\text { grade } 3 \\
\text { grade } 4\end{array}$ & $\begin{array}{c}15(18 \%) \\
25(30 \%) \\
38(46 \%) \\
5(6 \%) \\
0(0 \%)\end{array}$ & $\begin{array}{c}49(55 \%) \\
25(28 \%) \\
14(16 \%) \\
1(1 \%) \\
0(0 \%)\end{array}$ \\
\hline $\begin{array}{l}\text { Mycosis } \\
\text { none } \\
\text { moderate } \\
\text { severe }\end{array}$ & $\begin{array}{l}39(47 \%) \\
26(31 \%) \\
18(22 \%)\end{array}$ & $\begin{array}{c}58(65 \%) \\
22(25 \%) \\
9(10 \%)\end{array}$ \\
\hline $\begin{array}{c}\text { Dysphagia } \\
\text { none } \\
\text { moderate } \\
\text { severe }\end{array}$ & $\begin{array}{c}9(11 \%) \\
39(47 \%) \\
35(42 \%)\end{array}$ & $\begin{array}{c}25(28 \%) \\
58(65 \%) \\
6(7 \%)\end{array}$ \\
\hline $\begin{array}{l}\text { Pain } \\
\text { none } \\
\text { moderate } \\
\text { severe }\end{array}$ & $\begin{array}{l}18(22 \%) \\
37(45 \%) \\
27(33 \%)\end{array}$ & $\begin{array}{c}50(56 \%) \\
37(42 \%) \\
2(2 \%)\end{array}$ \\
\hline $\begin{array}{c}\text { Xerostomia } \\
\text { none } \\
\text { moderate } \\
\text { severe }\end{array}$ & $\begin{array}{c}8(10 \%) \\
33(40 \%) \\
41(49 \%)\end{array}$ & $\begin{array}{c}60(67 \%) \\
27(30 \%) \\
2(2 \%)\end{array}$ \\
\hline
\end{tabular}

Table 3: Incident of acute toxicity in two groups of patients. 


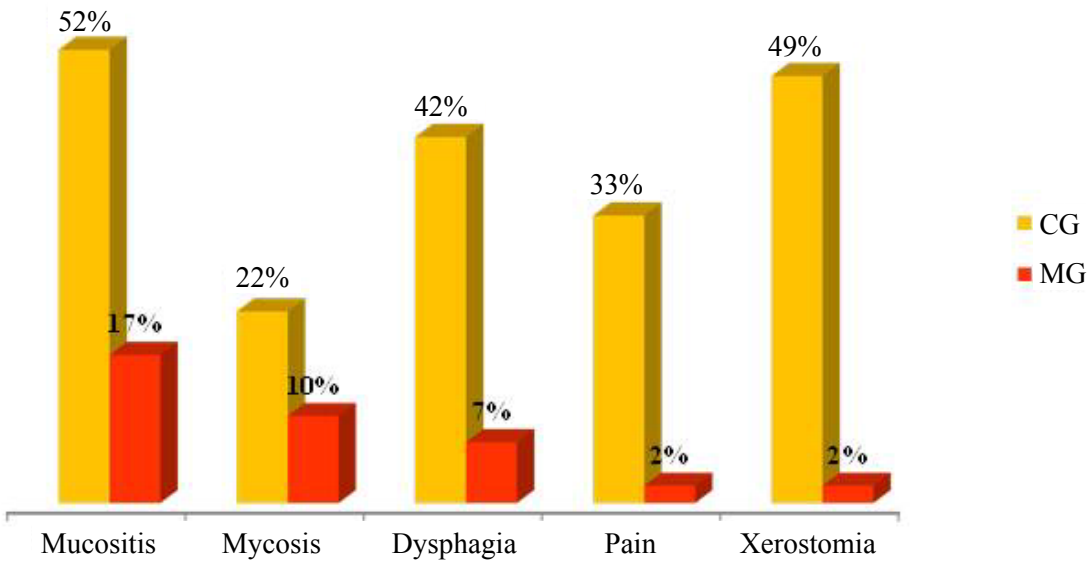

Figure 1: The percentages of severe acute toxicity in two groups of patients.

\begin{tabular}{|c|c|c|c|c|c|c|c|c|c|}
\hline \multicolumn{5}{|c|}{ CG } & \multicolumn{5}{|c|}{ MG } \\
\hline \multirow[t]{2}{*}{ Technique } & \multicolumn{4}{|c|}{ Toxicity } & \multirow[t]{2}{*}{ Technique } & \multicolumn{4}{|c|}{ Toxicity } \\
\hline & Mucositis & Mycosis & Xerostomia & Pain & & Mucositis & Mycosis & Xerostomia & Pain \\
\hline $\begin{array}{c}\text { 3DCRT-IMRT } \\
\text { Parotid gland dx } \\
47(0-67) \text { Parotid } \\
\text { gland sn } \\
47(7-87)\end{array}$ & $\begin{array}{l}\text { Grade } \\
0=4 \% \\
1=33 \% \\
2=52 \% \\
3=11 \%\end{array}$ & $\begin{array}{c}\text { Grade } \\
0=37 \% \\
1=37 \% \\
2=26 \% \\
3=0 \%\end{array}$ & $\begin{array}{c}\text { Grade } \\
0=7 \% \\
1=35 \% \\
2=59 \% \\
3=0 \%\end{array}$ & $\begin{array}{c}\text { Grade } \\
0=15 \% \\
1=50 \% \\
2=35 \% \\
3=0 \%\end{array}$ & $\begin{array}{c}\text { 3DCRT - IMRT } \\
\text { Parotid gland dx } \\
43(0-49) \text { Parotid } \\
\text { gland sn } \\
41(0-56) \\
\\
\text { TOMOTHERAPY } \\
\text { Parotid gland dx } \\
25(1-48) \text { Parotid } \\
\text { gland sn } \\
24(0-51)\end{array}$ & $\begin{array}{c}\text { Grade } \\
0=0 \% \\
1=18 \% \\
2=73 \% \\
3=9 \% \\
\text { Grade } \\
0=61 \% \\
1=36 \% \\
2=6 \% \\
3=0 \%\end{array}$ & $\begin{array}{c}\text { Grade } \\
0=36 \% \\
1=64 \% \\
2=0 \% \\
3=0 \% \\
\text { Grade } \\
0=55 \% \\
1=21 \% \\
2=24 \% \\
3=0 \%\end{array}$ & $\begin{array}{c}\text { Grade } \\
\begin{aligned} 0=27 \% \\
1=73 \% \\
2=0 \% \\
3=0 \% \\
\text { Grade } \\
0=70 \% \\
1=27 \% \\
2=3 \% \\
3=0 \%\end{aligned}\end{array}$ & $\begin{array}{c}\text { Grade } \\
0=27 \% \\
1=73 \% \\
2=0 \% \\
3=0 \% \\
\text { Grade } \\
0=64 \% \\
1=36 \% \\
2=0 \% \\
3=0 \%\end{array}$ \\
\hline
\end{tabular}

Table 4: Dmean parotid glands (median)

\section{Results}

Our first evaluation was about the percentage of occurrence of acute toxicity in patients of the two groups. In particular, we compared the toxicity of higher degree recognized in the two groups (Table 3 ).

In Figure 1 are shown the percentages of mucositis grade 2 and 3 , the percentage of severe fungal infections, dysphagia of grade 2 and 3 , severe pain and xerostomia grade 2 and 3 . The Figure 1 shows that the percentages of patients with high toxicity are significantly lower in Group Mucosyte.

The risk of adverse events in the Mucosyte Group and found a $P M$ (risk adverse $M G)=0.17$ with a $O M($ Odds of $M G)=0.20$, while the risk of adverse events in the Control Group showed a PC (risk adverse CG $)=0.52$ with a OC (Odds of CG $)=1.08$. We have at this point, calculated the odds ratio $\mathrm{OR}(\mathrm{OM} / \mathrm{OC})=0.19$, which showed a value in favor of the preventive treatment with Mucosyte ${ }^{\circ}$.

We calculated the probability for patients previously treated (MG), compared to $\mathrm{CG}$, of experiencing adverse event by calculating the relative risk $\mathrm{RR}(\mathrm{PM} / \mathrm{PC})=0.33$. It was showed that, in patients treated (MG) compared to CG, it is reduced the probability of an adverse event by calculating the relative risk reduction $\mathrm{RRR}(\mathrm{PC}-\mathrm{PM}) / \mathrm{PC}=0.67$. We also evaluated the difference in event rates between patients treated with Mucosyte ${ }^{\oplus}$ and CG, calculating the absolute risk reduction ARR $(\mathrm{PC}-\mathrm{PM})=0.35$

All parameters showed the effectiveness of the use of Mucosyte in the management of patients with head and neck cancer.
Moreover, considering the influence of the impairment of salivation on the integrity of the oral mucosa, we evaluated the correlation between acute toxicity and D mean to the parotid in other two homogeneous subgroups of patients, considering in particular only the patients with primary tumor localized to the nasopharynx, oropharynx and oral cavity, or patients exposed to high doses to the parotid glands (Table 4).

From the analysis of the data reported in the Table 4, it seem evident that there was a reduction of $\mathrm{D}$ mean on the parotid glands in patients treated with Tomotherapy in which the $\mathrm{D}$ mean usually respects the constraints dose rates of QUANTEC. This because Tomotherapy is an innovative technique in delivering an IMRT that consent to obtain a better conformity of dose. In the patients treated with Tomotherapy, the high degree of toxicity was lower than in patients treated with traditional 3DCRT or IMRT technique and moreover patients with none toxicity reached percentages ranging $55-70 \%$. About the incidence of mucositis, in the MG it was confirmed that the lower percentage is probably mostly influenced by the radiotherapy technique used. While for the xerostomia, mycosis and pain are much lower in the MG, independently from technique used. An important influence on the toxicity is due to chemotherapy. In the CG, the patients not receiving chemotherapy were $33 \%$ compared to $70 \%$ of MG. Patients undergoing chemotherapy pre-RT were $34 \%$ in the CG versus $16 \%$ in MG. Patients who underwent concomitant CT-RT were $23 \%$ in CG versus $2 \%$ in the MG. Patients treated with CT pre-RT and concomitant CT-RT were $11 \%$ in the CG versus $12 \%$ in MG.

\section{Discussion}

The pathogenesis of chemo-radiotherapy induced mucositis 
appears to be related to oxidative stress induced by the treatment and an important role in the activation process have the reactive oxygen species (ROS), which causes direct damage, and indirect damage through transcription factors such as nuclear factor $\mathrm{kB}(\mathrm{NF}-\mathrm{kB})$ that activates iNOS, and the activator protein 1 (AP-1), which induce the production of pro-inflammatory cytokines, such as TNF, IL-6 and IL-B $[23,24]$.

Important results deriving from the use of some substances that determine the reduction of severity of mucositis in the experimental model. Speranza et al. showed anti-inflammatory effects of the extract Verbascum thapsus by evaluating the enzymatic activity of the antioxidant enzymes and evaluating iNOS expression and activity in cell preparations NF- $\mathrm{kb}$. In pathological conditions, a fundamental role is played by transcription factor NFkB, that along with AP-1 mediates the expression of iNOS, similar to inducible genes such as cyclooxygenase-2 (COX-2) and ICAM-1 (intercellular cell adhesion molecule 1) in inflammatory and immune responses. They examined the role of Verbascoside in controlling TAK-responsive genes in the U937 cell line. TAK-1 is a novel protein that mediates pro-inflammatory signaling through induction of the transcription factor AP-1 with expression of inflammatory genes including COX-2. So Verbascoside decreased NOS activities, NF-kB activation and nuclear translocation and so may modulate inflammatory reactions representing a novel approach for treating inflammatory disease [25]. The molecularly targeted therapy with cetuximab was approved by the U.S. Food and Drug Administration in combination with radiation for treatment of patients with locally advanced head and neck cancers and for patients with recurrent, platinum-refractory disease. In a study of high-dose radiotherapy for head and neck cancer, the addition of cetuximab resulted in to lower rate of locoregional progression or death, a longer progression free survival time, and a longer overall survival time without exacerbating common adverse events, including ulcerative mucositis [26].

Our results showed the positive effect of the tolerability and efficacy of the product based Verbascoside, Polyvinylpyrrolidone and Hyaluronic Acid (Mucosyte ${ }^{\circledR}$ ) in the management of toxicities of patients with head and neck cancer.

In our experience with the two groups of patients, the antiinflammatory activity of Verbascoside is most evident if given in prevention, probably due to the polyvinylpyrrolidone's capability of forming a protective film of the oral mucosa and that of the sodium salt of hyaluronic acid to facilitate the processes reparative and reepithelialization assisting these processes in patients undergoing chemotherapy.

Previous studies have suggested that Verbascoside has an antiinflammatory property since it reduces the production of superoxide radicals and consequently Reduces the activity of iNOS and COX-2 $[27,28]$.

In Mucosyte ${ }^{\circledR}$ there is a synergetic action of active components. With the mucoadhesive properties of PVP, the transfer of Verbascoside and Hyaluronic Acid is continuous and progressive, allowing the explanation of the specific activities. Regarding the ability of the Verbascoside to act in the mechanisms of the inflammatory process, it is showed that it is involved in controlling TAK-l, a novel protein that mediates pro-inflammatory signaling through induction of the transcription factor AP-1 with expression of inflammatory genes including COX-2. The Verbascoside can prevent oxidative stress, in fact it has been demonstrated for the first time that the concomitant inhibition of the expression of NOS and COX-2 is due a reduction of the degradation of IkB-alfa in the cytosol resulting in inactivation of NF$\mathrm{kB}$ in core. Inhibition of pro-inflammatory cell migration to damaged skin would result in the moderate inflammatory response [29]. Oral mucositis pain is associated with release of pro-inflammatory cytokines and neurotransmitters that activate nociceptors at the site of injury and may be increased by secondary mucosal infection. Cyclooxygenase- 2 (COX-2) is up-regulated in mucositis; therefore COX-2 inhibitors represent potential agents that may affect pain and evolution of mucositis. Verbascoside is able to decrease the presence of COX-2 [30].

We also consider important the data derived from the assessment of the doses received by parotid glands, by virtue of the fact that the impairment of salivary function predisposes to an alteration of the balance and integrity of the oral mucosa.

Monitoring of the oral cavity side effects should be constantly performed during radiation therapy in an effort to decrease the severity of side effects. The oral tissues directly affected by head and neck radiation therapy include the salivary glands, the mucosal membranes, the jaw muscles and bone. Dry mouth (xerostomia) is a common and significant consequence of head and neck radiotherapy. Because of the loss of saliva, patients with xerostomia are more susceptible to periodontal disease, rampant caries, and oral fungal and bacterial infections. Mucositis, characterized by inflammation and ulceration of the oral mucosa, is the most significant acute side effect reported by patients and is a potential source of life-threatening infection. Almost all patients undergoing head and neck radiation therapy experience confluent mucositis by approximately the third week of treatment [31,32].

Probably one limit of our study is that it is retrospective with an observational character; moreover patients have been treated with different techniques. Certainly the management of the toxicity of radio chemotherapy in patients with head and neck is timelier than ever, in fact treatment guidelines for oral mucositis were issued in 2004 and recently were updated by the Multinational Association of Supportive Care in Cancer and International Society for Oral Oncology (MASCC/ ISOO) [33]. We also evaluated the differences liked to the use of the Tomotherapy IMRT compared with the treatments delivered with 3DCRT or IMRT in the CG and MG groups. The Grade 2 mucositis appearance is dramatically reduced by the use of Thomoterapy in the MG group. Excluding this difference, all the others advantages in the MG group can be related to the use in the preventive asset of Mucosyte ${ }^{ø}$ ).

These guidelines emphasize basic oral care, an interdisciplinary approach to oral care, routine assessment of oral care and pain management using validated instruments, and regular dental assessment and dental care prior to the start of cancer therapy [34].

Oral mucositis is an extremely serious complication of both radiation and chemotherapy in cancer patients. Pretreatment should be aimed to reduce systemic infection, patient's nutritional status should not be compromised, and patient's quality of life should not be affected. A number of agents have been evaluated in clinical trials, but currently none of them has succeeded in reaching clinical practice. Some of the parameters to be evaluated include the release of free radicals, modified proteins, and proinflammatory cytokines including interleukin-1B, prostaglandins, and TNF by epithelial, endothelial, and connective tissue cells. These mediators cause further damage either directly or indirectly by increasing vascular permeability, enhancing the cytotoxic drug in the oral mucosa [35].

The most common ingredients include viscous lidocaine, 
Citation: Di Franco R, Muto M, Ravo V, Borrelli D, Pepe A, et al. (2014) Oral Mucositis related to Radiotherapy for Head and Neck cancer: Evaluation of the Effectiveness of a New Anti-inflammatory Product Containing Verbascoside, Polyvinylpyrrolidone, Hyaluronic Acid (Mucosyte ${ }^{\circledR}$ ). Pharm Anal Acta 5: 312. doi:10.4172/2153-2435.1000312

benzocaine, milk of magnesia, kaolin, pectin, chlorhexidine, and dyphenhydramine. Topical analgesics that can be considered include the single agents benzydamine and morphine. Many topical agents have been compounded in mixtures. There is no significant evidence of the effectiveness or tolerability of these mixtures [36-45].

\section{Conclusion}

Using Verbascoside fluid (Mucosyte ${ }^{\circledR}$ ) previously and until two weeks from the end of RT (MG) the incidence of muscositis is lower but this result is influenced also by technique. Xerostomia, mycosis and pain are much lower in the patient that used Verbascoside fluid (Mucosyte $^{\oplus}$ ) in prevention (MG) independently from technique used. In order to underline the importance of the management of patients with head and neck cancer, and to identify products that could allow an adequate control of toxicity in the oral mucosa, we think it is important to continue the evaluation of the use of Mucosyte ${ }^{\oplus}$, but also with a prospective study extended to other centers to evaluate a larger number of patients.

\section{Acknowledgement}

We thank Martina Samarelli for helping us to manage the patient's database.

\section{References}

1. Budach W, Hehr T, Budach V, Belka C, Dietz K (2006) A meta-analysis of hyperfractionated and accelerated radiotherapy and combined chemotherapy and radiotherapy regimens in unresected locally advanced squamous cell carcinoma of the head and neck, BMC Cancer 6:28.

2. Adelstein DJ, Li Y, Adams GL, Wagner H Jr, Kish JA, et al. (2003) An intergroup phase III comparison of standard radiation therapy and two schedules of concurrent chemoradiotherapy in patients with unresectable squamous cell head and neck cancer, J ClinOncol 21:92-98.

3. Bernier J, Domenge C, Ozsahin M, Matuszewska K, Lefèbvre JL, et al. (2004) Postoperative irradiation with or without concomitant chemotherapy for locally advanced head and neck cancer, N Engl J Med. May 350: 1945-1952.

4. Brizel DM, Albers ME, Fisher SR, Scher RL, Richtsmeier WJ, et al. (1998) Hyperfractionated irradiation with or without concurrent chemotherapy for locally advanced head and neck cancer. See comment in PubMed Commons below N Engl J Med 338: 1798-1804.

5. Calais G, Alfonsi M, Bardet E, Sire C, Germain T, et al. (1999) Randomized tria of radiation therapy versus concomitant chemotherapy and radiation therapy for advanced stage oropharynx carcinoma, J Natl Cancer Inst 91:2081-2086.

6. Denis F, Garaud P, Bardet E, Alfonsi M, Sire C (2004) Final results of the 94-01 French Head and Neck Oncology and Radiotherapy Group randomized trial comparing radiotherapy alone with concomitant radiochemotherapy in advanced-stage oropharynx carcinoma. J ClinOncol 22: 69-76.

7. Cooper JS, Pajak TF, Forastiere AA, Jacobs J, Campbell BH, et al. (2004) Radiation Therapy Oncology Group 9501/Intergroup - Postoperative concurrent radiotherapy and chemotherapy for high-risk squamous-cell carcinoma of the head and neck, N Engl J Med 350: 1937-1944.

8. Forastiere AA, Goepfert H, Maor M, Pajak TF, Weber R, et al. (2003) Concurrent chemotherapy and radiotherapy for organ preservation in advanced laryngeal cancer. See comment in PubMed Commons below N Engl J Med 349: 2091 2098.

9. Staar S, Rudat V, Stuetzer H, Dietz A, Volling P, et al. (2001) Intensified hyperfractionated accelerated radiotherapy limits the additional benefit of simultaneous chemotherapy--results of a multicentric randomized German trial in advanced head-and-neck cancer, Int J RadiatOncolBiol Phys 50:1161-1171.

10. Pignon JP, Bourhis J, Domenge C, Designé L (2000) Chemotherapy added to locoregional treatment for head and neck squamous-cell carcinoma: three meta-analyses of updated individual data. MACH-NC Collaborative Group. Meta-Analysis of Chemotherapy on Head and Neck Cancer, Lancet 355:949955.

11. Zlotolow IM (1998) General consideration in prevention and treatment of oral manifestation of cancer therapies. Principles and Practice of Supportive Oncology. Lippincott Raven, Philadelphia, PA. Pp: 237.
12. Bitran JD, Samuel B, Klein L, Hanauer S, Johnson L, et al. (1996) Random high dose chemotherapy supported by hematopoietic progenitor cells yields prolonged survival in stage IV breast cancer, Bone Marrow Transplant 17: 157162.

13. Woo SB, Sonis ST, Monopoli MM, Sonis AL (1993) A longitudinal study of ora ulcerative mucositis in bone marrow transplant recipients. See comment in PubMed Commons below Cancer 72: 1612-1617.

14. Kolbinson DA, Schubert MM, Flournoy N, Truelove EL (1988) Early ora changes following bone marrow transplantation. See comment in PubMed Commons below Oral Surg Oral Med Oral Pathol 66: 130-138.

15. Toth BB, Martin JW, Fleming TJ (1990) Oral complications associated with cancer therapy. An M. D. Anderson Cancer Center experience. See comment in PubMed Commons below J Clin Periodontol 17: 508-515.

16. Jansma J, Vissink A, Bouma J, Vermey A, Panders AK, et al. (1992) A survey of prevention and treatment regimens for oral sequelae resulting from head and neck radiotherapy used in Dutch radiotherapy institutes. See comment in PubMed Commons below Int J Radiat Oncol Biol Phys 24: 359-367.

17. Jansma J, Vissink A, Spijkervet FK, Roodenburg JL, Panders AK, et al. (1992) Protocol for the prevention and treatment of oral sequelae resulting from head and neck radiation therapy. See comment in PubMed Commons below Cance 70: 2171-2180.

18. Epstein JB, Emerton S, Kolbinson DA, Le ND, Phillips N, et al. (1999) Quality of life and oral function following radiotherapy for head and neck cancer. See comment in PubMed Commons below Head Neck 21: 1-11.

19. Epstein JB, Robertson M, Emerton S, Phillips N, Stevenson-Moore P (2001) Quality of life and oral function in patients treated with radiation therapy for head and neck cancer. See comment in PubMed Commons below Head Neck 23: 389-398.

20. McElroy TH, Guerra ON (1984) Oral/dental management of the head and neck radiation therapy patient. See comment in PubMed Commons below Mo Med 81: 15-18.

21. Worthington HV, Clarkson JE, Eden OB (2007) Interventions for preventing oral mucositis for patients with cancer receiving treatment. See comment in PubMed Commons below Cochrane Database Syst Rev : CD000978.

22. Moseley R, Waddington RJ, Embery G (2002) Hyaluronan and its potential role in periodontal healing. See comment in PubMed Commons below Dent Update 29: 144-148.

23. Wong WR, Kossodo S, Kochevar IE (2001) Influence of cytokines on matrix metalloproteinases produced by fibroblasts cultured in monolayer and collagen gels. See comment in PubMed Commons below J Formos Med Assoc 100: 377-382.

24. Herouy $Y$ (2001) Matrix metalloproteinases in skin pathology (Review). See comment in PubMed Commons below Int J Mol Med 7: 3-12.

25. Speranza L, Franceschelli S, Pesce M, Reale M, Menghini L, et al. (2010) AntiinflammatoryEffects in THP-1 cellsTreated withVerbascoside, Phytother Res 24: 1398-1404.

26. Bonner JA, Harari PM, Giralt J, Azarnia N, Shin DM, et al. (2006) Radiotherapy plus cetuximab for squamous-cell carcinoma of the head and neck. See comment in PubMed Commons below N Engl J Med 354: 567-578.

27. Perch SJ, Machtay M, Markiewicz DA, Kligerman MM (1995) Decreased acute toxicity by using midline mucosa-sparing blocks during radiation therapy fo carcinoma of the oral cavity, oropharynx, and nasopharynx. See comment in PubMed Commons below Radiology 197: 863-866.

28. Ship JA, Eisbruch A, D'Hondt E, Jones RE (1997) Parotid sparing study in head and neck cancer patients receiving bilateral radiation therapy: one-year results. See comment in PubMed Commons below J Dent Res 76: 807-813.

29. Speranza L, Franceschelli S, Pesce M, Reale M, Menghini L, et al. (2010) Antiinflammatory effects in THP-1 cells treated with verbascoside. See comment in PubMed Commons below Phytother Res 24: 1398-1404.

30. "Oral Complications of Chemotherapy and Head/Neck Radiation" , National Cancer Institute - National Institutes of Health.

31. Foote RL, Loprinzi CL, Frank AR, O'Fallon JR, Gulavita S, et al. (1994) Randomized trial of a chlorhexidine mouthwash for alleviation of radiationinduced mucositis. See comment in PubMed Commons below $\mathrm{J}$ Clin Oncol 12: $2630-2633$. 
Citation: Di Franco R, Muto M, Ravo V, Borrelli D, Pepe A, et al. (2014) Oral Mucositis related to Radiotherapy for Head and Neck cancer: Evaluation of the Effectiveness of a New Anti-inflammatory Product Containing Verbascoside, Polyvinylpyrrolidone, Hyaluronic Acid (Mucosyte ${ }^{\circledR}$ ). Pharm Anal Acta 5: 312. doi:10.4172/2153-2435.1000312

Page 6 of 6

32. Epstein JB, Silverman S Jr, Paggiarino DA, Crocket S, Schubert MM, et al. (2001) BenzydamineHCl for prophylaxis of radiationinduced oral mucositis: results from a multicenter, randomized, doubleblind, placebo-controlled clinical trial. Cancer 92: 875-885

33. McGuire DB, Correa ME, Johnson J, Wienandts $\mathrm{P}$ (2006) The role of basic oral care and good clinical practice principles in the management of oral mucositis. See comment in PubMed Commons below Support Care Cancer 14: 541-547.

34. Sol Silverman (2006) Chicago Supportive Oncology Conference, Review Diagnosis and Management of Oral Mucositis, Chicago, Illinois.

35. Naidu MU, Ramana GV, Rani PU, Mohan IK, Suman A, et al. (2004) Chemotherapy-induced and/or radiation therapy-induced oral mucositiscomplicating the treatment of cancer. See comment in PubMed Commons below Neoplasia 6: 423-431.

36. Dudjak LA (1987) Mouth care for mucositis due to radiation therapy. See comment in PubMed Commons below Cancer Nurs 10: 131-140.

37. Levy-Polack MP, Sebelli P, Polack NL (1998) Incidence of oral complications and application of a preventive protocol in children with acute leukemia. See comment in PubMed Commons below Spec Care Dentist 18: 189-193.

38. Carnel SB, Blakeslee DB, Oswald SG, Barnes M (1990) Treatment of radiationand chemotherapy-induced stomatitis. See comment in PubMed Commons below Otolaryngol Head Neck Surg 102: 326-330.
39. Rothwell BR, Spektor WS (1990) Palliation of radiation-related mucositis. See comment in PubMed Commons below Spec Care Dentist 10: 21-25.

40. Spijkervet FK, Van Saene HK, Van Saene JJ, Panders AK, Vermey A, et al. (1991) Effect of selective elimination of the oral flora on mucositis in irradiatedhead and neck cancer patients. See comment in PubMed Commons below J Surg Oncol 46: 167-173.

41. Sedal-Turhal N, Erdal S, Karacay S (2000) Efficacy of treatment to relieve mucositis-induced discomfort, Support Care Cancer 8: 55-58

42. Dodd MJ, Larson PJ, Dibble SL, Miaskowski C, Greenspan D, et al. (1996) Randomized clinical trial of chlorhexidine versus placebo for prevention of oral mucositis in patients receivingchemotherapy, OncolNurs Forum 23:921-927.

43. Dodd MJ, Dibble SL, Miaskowski C, MacPhail L, Greenspan D, et al. (2000) Randomized clinical trial of the effectiveness of 3 commonly used mouthwashes to treat chemotherapy-induced mucositis. Oral Surg Oral Med Oral Pathol Oral RadiolEndod 90:39-47.

44. Bondi E, Baroni C, Prete A, Gatti M, Carrassi A, et al. (1997) Local antimicrobial therapy of oral mucositis in paediatric patients undergoing bone marrow transplantation. Oral Oncol 33:322-326.

45. Coetzee MJ, Boshoff B, Goedhals L, Pienaar FD (1997) Formula C--popular, cheap and readily available relief for radiation and cancer chemotherapy mucositis. See comment in PubMed Commons below S Afr Med J 87: 80-81. 